\title{
The instrument-centering ability of four Nickel-Titanium instruments in simulated curved root canals
}

\author{
Jae-Hoon Ku', Hoon-Sang Chang', Seok-Woo Chang', Hwan-Hee Cho', Ji-Myung Bae², Kyung-San Min'* \\ ${ }^{\prime}$ Department of Conservative Dentistry, ${ }^{2}$ Department of Dental Biomaterials \\ College of Dentistry, Wonkwang University
}

\begin{abstract}
The aim of this study was to evaluate the ability of newly marketed NRT instruments to maintain the original root canal configuration and curvature during preparation in comparison with the three existing instruments in simulated root canals.

Simulated canals in resin blocks were prepared with ProFile, K3, ProTaper, and NRT instrument ( $\mathrm{n}=10$ canals in each case). Pre- and post-operative images were recorded, and assessment of canal shape was completed with a computer image analysis program. The data were analyzed statistically using the One-way ANOVA followed by Duncan's test.

The ability of instruments to remain centered in prepared canals at $1^{-}, 2^{-m m}$ levels was significantly better in ProFile groups than in other groups $(p<0.05)$. The change of centering ratio in NRT groups at 5-mm level was significantly greater than ProFile group and at $6^{-}$and 7 -mm level than all other groups $(p<0.05)$.

Although the NRT system was comparable to other systems in regards to its ability to maintain the canal configuration of apical portion, this system was more influenced by the mid-root curvature due to its stainless-steel files for coronal preflaring. [J Kor Acad Cons Dent 31(2):113-118, 2006]
\end{abstract}

Key words : Nickel-titanium, Simulated canal, Centering ratio, NRT, Stainless-steel

- Received 2005.12.15., revised 2006.1.14., accepted 2006.2.9. -

\section{I . INTRODUCTION}

The aim of root canal preparation is to clean and shape the root canal system while maintaining the original configuration. However, traditional hand instruments often failed in achieving these objec-

\footnotetext{
* Corresponding Author: Kyung-San Min
}

Department of Conservative Dentistry, College of Dentistry, Wonkwang University 344-2 Shinyong-dong, Iksan, Cheonbuk, Korea, 570-749 Tel: 82-63-850-6930 Fax: 83-63-850-1932 Email:mksdd@wonkwang.ac.kr tives, especially when used in severely curved canals $^{1.22}$. Over the years, many nickel-titanium rotary instruments have been developed to improve root canal preparation. More flexible files made of nickel-titanium have been effective in minimizing complications in severely curved canal preparation ${ }^{3.4)}$. They are available in various designs that differ in tip and taper design, rake angles, helical angles, pitch, and presence of radial lands. Recently, new Ni-Ti rotary instrument with stainless-steel orifice shaper and quasi-rectangular cross sectional shape, NRT (Mani,

* This paper was supported by Wonkwang University in 2005. 
Nakaakutsu, Japan) was introduced.

The purpose of this study is to determine the shaping ability of newly marketed NRT instruments in comparison with the 3 existing instruments, ProFile (Dentsply-Maillefer, Ballaigues, Switzerland), K3 (SybronEndo, West Collins, CA, USA), ProTaper (Dentsply-Maillefer, Ballaigues, Switzerland) in simulated root canals.

\section{MATERIALS AND METHODS}

A total of forty simulated curved root canals in clear resin blocks (Dentsply-Maillefer, Ballaigues, Switzerland) were used for this study. An apical foramen size of $0.15 \mathrm{~mm}$ was confirmed, and each canal had a mean canal length of $17 \mathrm{~mm}$. The blocks were divided into 4 groups according to the instruments used: ProFile, K3, ProTaper and NRT. Aqueous red ink was injected into the canals to enhance the image contrast. These resin blocks were scanned in a reproducible position with a scanner, and then the image data were stored in a computer. Before the $\mathrm{Ni}-\mathrm{Ti}$ files were used, the canals were explored with stainless steel No.10 and 15 hand K-files until the tip was visible at the apical foramen. The working lengths were established to apical foramen.

\section{Preparation of simulated canals}

Group 1 (ProFile) was instrumented in a crowndown manner at a constant speed of $300 \mathrm{rpm}$ with ProFile 06 taper instruments. Orifice Shapers 3 and 2 were used for coronal shaping until resistance was encountered. A variable tip sequence was used in a crown-down sequence until the canal was prepared to an instrument size 30 at 0.06 taper canal terminus. In group 2 (K3), the canals were prepared with K3 .06 taper files in the same manner as group 1 to a file size 30 at a .06 taper instruments. In group 3 (ProTaper), a S1 shaping file was used first and moved apically to $2 \mathrm{~mm}$ short of the working length. SX files were then used until resistance was encountered, followed by S1 and S2 to the working length for the shaping of the coronal two thirds of the canal. The apical portion was finished by using F1, F2 sequentially to the working length. F3 file was not used. In group 4 (NRT), the canals were prepared with NRT .06 taper instrument. SS files were used to enlarge the canal orifices and .06 NiTi files used to prepare the mid-root and apical portions of the canals to an instrument size 30 at .06 taper canal terminus.

\section{Assessment of canal preparation}

All photographs were scanned into the computer and processed by an examiner who was blinded with respect of all to the experimental groups. Using Photoshop 6.0 program (Adobe System Inc., USA), the post-operative canal images were superimposed over the pre-operative images by superposing the three dots selected in the preand post-instrumented images at the same positions. The change of canal curvature was measured by the Schneider method ${ }^{5)}$. The ability of instruments to remain centered in the canal was determined by calculating a centering ratio after perpendicular lines were made from the canal axes at $1^{-}, 2^{-}, 3^{-}, 4^{-}, 5^{-}, 6^{-}$, and 7-mm levels from

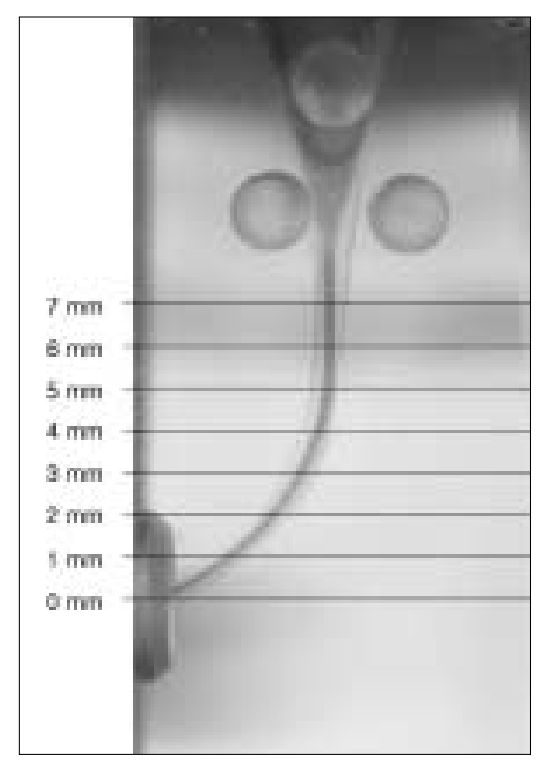

Figure 1. A diagram indicate the points at which the canal width were measured after superimposition of pre-operative and post-operative images. 
the working length with Image analyzer (Figure 1). Observing and measuring the original canals position in the canals instrumented, the centering ratio was calculated by the formula $(\mathrm{X} 1-\mathrm{X} 2) / \mathrm{Y}$

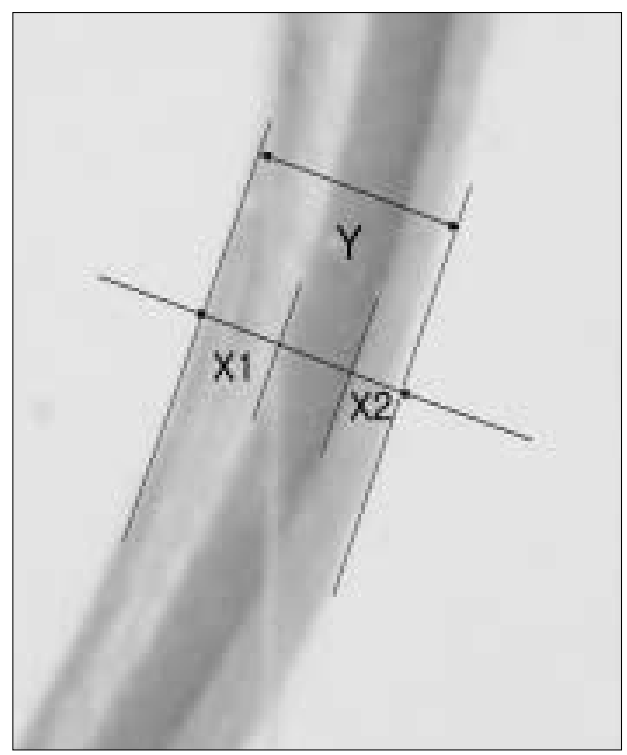

Figure 2. X1 represents the maximum extent of canal movement in one direction and $\mathrm{X} 2$ is the movement in the opposite direction. $\mathrm{Y}$ is the diameter of the final canal preparation.
¿X1 represents the maximum extent of canal movement in one direction and $\mathrm{X} 2$ is the movement in the opposite direction. $\mathrm{Y}$ is the diameter of the final canal preparation] ${ }^{6)}$ (Figure 2).

\section{Recording, storage, and analysis of data}

All data were stored on PC from the image processing software directly to a database file. Following error and range checks, the data were analyzed using SPSS, statistical analysis program. Change of canal curvature and differences of centering ratio at the 7 measuring points were statistically analyzed using One-way ANOVA followed by Duncan's test.

\section{RESULTS}

\section{Change in canal curvature}

A greater decrease in curvature was observed in the ProTaper group than in the other groups. However, there was no statistical difference $(p>$ 0.05, Table 1).

Table 1. Canal curvature measured by the Schneider method

\begin{tabular}{cccc}
\hline & Before instrumentation & After instrumentation & change \\
\hline ProFile & $122.09 \pm 2.31$ & $130.75 \pm 2.01$ & $8.66 \pm 1.41$ \\
K3 & $130.75 \pm 2.01$ & $132.77 \pm 2.12$ & $9.31 \pm 1.46$ \\
ProTaper & $122.18 \pm 1.80$ & $131.99 \pm 3.44$ & $9.81 \pm 2.68$ \\
NRT & $123.03 \pm 2.05$ & $131.79 \pm 1.97$ & $8.76 \pm 2.87$ \\
\hline
\end{tabular}

Values are mean $\pm \mathrm{SD}, \mathrm{n}=10$ in each group.

Table 2. Means centering ratio at different level

\begin{tabular}{cccccccc}
\hline & $1 \mathrm{~mm}$ & $2 \mathrm{~mm}$ & $3 \mathrm{~mm}$ & $4 \mathrm{~mm}$ & $5 \mathrm{~mm}$ & $6 \mathrm{~mm}$ & $7 \mathrm{~mm}$ \\
\hline ProFile & $.08 \pm .05^{\mathrm{a}}$ & $.07 \pm .05^{\mathrm{a}}$ & $.17 \pm .09$ & $.32 \pm .11$ & $.27 \pm .10^{\mathrm{ab}}$ & $.06 \pm .05^{\mathrm{a}}$ & $.09 \pm .05^{\mathrm{a}}$ \\
K3 & $.19 \pm .07^{\mathrm{b}}$ & $.17 \pm .07^{\mathrm{b}}$ & $.27 \pm .11$ & $.41 \pm .13$ & $.31 \pm .11^{\mathrm{b}}$ & $.10 \pm .05^{\mathrm{a}}$ & $.11 \pm .02^{\mathrm{a}}$ \\
ProTaper & $.17 \pm .07^{\mathrm{b}}$ & $.13 \pm .05^{\mathrm{b}}$ & $.25 \pm .05$ & $.42 \pm .08$ & $.31 \pm .13^{\mathrm{b}}$ & $.12 \pm .07^{\mathrm{a}}$ & $.14 \pm .09^{\mathrm{a}}$ \\
NRT & $.18 \pm .07^{\mathrm{b}}$ & $.16 \pm .09^{\mathrm{b}}$ & $.25 \pm .13$ & $.36 \pm .15$ & $.41 \pm .08^{\mathrm{bc}}$ & $.20 \pm .07^{\mathrm{b}}$ & $.18 \pm .06^{\mathrm{b}}$ \\
\hline
\end{tabular}

Values are mean $\pm \mathrm{SD}, \mathrm{n}=10$ in each group. Groups identified by different symbols are significantly different at the same apical levels $(p<0.05)$. Groups identified by the same symbols are not significantly different $(\mathrm{p}>0.05)$. 


\section{Change in centering ratio of canals}

The ability of instruments to remain centered in prepared canals at $1-$ and 2 -mm levels was significantly better in ProFile groups than in other groups $(p<0.05)$. K3, NRT, and ProTaper groups presented similar change in centering ratio at $1^{-}$, $2^{-}, 3^{-}, 4^{-m m}$ levels $(p>0.05$ ). The change of centering ratio in NRT groups at $5-\mathrm{mm}$ level was significantly greater than ProFile group and at 6and $7-\mathrm{mm}$ level than all other groups $(\mathrm{p}<0.05$, Table 2).

\section{DISCUSSION}

The aim of this study was to determine the shaping ability of NRT instruments in comparison with the 3 existing instruments in simulated root canals under controlled laboratory conditions.

The centering ratio can define the ability of instruments to remain centered in shaped canals. According to the formula, the centering ratio approaches zero as X1 and X2 become closer. The lower the score, the better the instruments centered in the canal. In this present study, the results of the centering ratio in four groups at $1^{-}$, 2-mm levels indicated that the ability of instruments to remain centered in prepared canals was significantly better in Profile groups than in other groups. The ProFile instrument family, including ProFile .04 and .06 taper, Orifice Shapers, all have the same cross-sectional geometry, which is made by machining three equally spaced Ushaped grooves around the shaft of a taper $\mathrm{Ni}-\mathrm{Ti}$ wire. There is a central parallel core inside that may account for the enhanced flexibility compared with Quantec ${ }^{7)}$ and ProTaper ${ }^{8)}$.

It was shown that 3 groups except ProFile group presented similar change in centering ratio at $1^{-}$, $2^{-}, 3^{-}, 4^{-m m}$ levels. In previous studies it was suggested that ProTaper instruments caused greater widening of canals and lessened the canal curvature compared to other instruments ${ }^{9.10)}$. In most of these studies, however, all finishing files including F3 were used to working length. All three finishing files have a fixed taper in the first $3 \mathrm{~mm}$ from D0 to D3. F1 has a taper of 7\%, F2 has a taper of $8 \%$, and F3 has a taper of $9 \%$ in this region. Over the remaining length of the cutting blade, a reverse taper can be found. The diameter of F3 file at $3-\mathrm{mm}$ level is then $0.57 \mathrm{~mm}$ and it is much greater than that of .06 tapered \#30 instruments. Yoshimine et $\mathrm{l}^{\left.9^{9}\right)}$ suggested that .06 tapered files could be used for apical preparation without creating severe aberrations, if smaller, less-tapered files were used before the use of .06 tapered ones. On the other hand, the ProTaper group showed a tendency toward apical irregularities, such as ledge and zip, despite the single slight-pressure-and-withdrawal motion of a finishing file at the end-point of preparation after instrumentation using F3 file. In this respect, F3 file was not used to avoid possible canal deviation in the present study. Guelzow et $a 1^{11)}$ reported that six rotary nickel-titanium systems including K3 and ProTaper instruments maintained the original canal curvature well with minor mean degrees of straightening. Iqbal et $a 1^{12)}$ concluded that both ProTaper and ProFile instruments are comparable to each other in regards to their ability to optimally enlarge root canal with minimal transportation and loss of working length in vitro.

It was also shown that the change of centering ratio in NRT groups at 5-, 6-, and 7-mm level was significantly greater than other groups. In the simulated resin blocks used in this study $5-\mathrm{mm}^{-} \mathrm{lev}^{-}$ el fell under beginning of curvature and the files for coronal shaping such as Orifice shaper in ProFile, Orifice opener in K3, and SS file in NRT were used up to this point.

The NRT files consist of the stainless-steel files used to enlarge the root canal orifices and $\mathrm{Ni}-\mathrm{Ti}$ files used to prepare the mid-root and apical portions of the canal space for the continuous taper preparation. Weine ${ }^{13)}$ found that stainless steel files tended to straighten curved canals. Davis et al ${ }^{14)}$ reported that working length decreased as a result of canal preparation and the mean decrease in working length was significantly greater for the stainless steel group (SS hand files + Gates Glidden drills) than for the Ni-Ti group. They speculated that the differences found between 
stainless steel and $\mathrm{Ni}^{-} \mathrm{Ti}$ instruments are due to the superior ability of $\mathrm{Ni}-\mathrm{Ti}$ to remain centered within the canal during instrumentation, thus minimizing the straightening of the canal.

The cross-section of the NRT Ni-Ti files is a Quasi-rectangle. It is suggested that this shape allows for improved file flexibility and improved cutting ability. It is also asserted that there are less possibilities for pushing debris toward root apex and danger of forcing them out of the apical foramen can be minimized with their deep space between cutting blades. However, this instrument system adopted stainless-steel as a file for preparing coronal part of root canal. In this respect, we can explain the reason why the change of canal configuration in this part was significantly greater in NRT group than in other groups.

To assess instrumentation of curved canals, clear resin blocks were used in this study. These were chosen because shape, size, taper, and curvature of the experimental canals are standardized. The credibility of resin blocks as an ideal experimental model for the analysis of endodontic preparation and preparation techniques has been validated by Weine et al. ${ }^{13)}$ and Dummer et al. ${ }^{15)}$. However there are limitations with the model, such as the different hardness between resin and dentin, and care should be exercised in the extrapolation of the present results to the use of these instruments in the clinical situation. Nevertheless, the use of simulated canals in resin blocks results in the opportunity to standardized the research method and to exclude parameters that could influence the preparation outcome.

\section{CONCLUSION}

The results indicate that ProFile system is more suitable than other instruments in the apical preparation of canals with a complicated curvature. Although the NRT system was comparable to other systems in regards to its ability to maintain the canal configuration of apical portion, this system was more influenced by the mid-root curvature due to its stainless-steel files for coronal preflaring.

\section{REFERENCES}

1. Al-Omari MAO, Dummer PMH, Newcombe RG. Comparison of six files to prepare simulated root canals. Part 2. Int Endod J 25:67-81, 1992.

2. Schafer E, Tepel J, Hoppe W. Properties of endodontic hand instruments used in rotary motion. Part 2. Instrumentation of curved canals. J Endod 21:493497, 1995

3. Wu MK, Wesselink PR. Efficacy of three techniques in cleaning the apical portion of curved canals. Oral Surg Oral Med Oral Pathol 79:492-496, 1995.

4. Zmener O, Banegas G. Comparison of three instrumentation techniques in the preparation of simulated root canals. Int Endod J 29:315-319, 1996.

5. Schneider SW. A comparison of canal preparations in straight and curved root canals. Oral surg 32:271-275, 1971.

6. Calhoun G, Montgomery S. The effects of four instrumentation techniques on root canal shape. J Endod 14:273-277, 1988.

7. Peters OA, Schonenberger K, Laib A. Effects of four $\mathrm{Ni}-\mathrm{Ti}$ preparation techniques on root canal geometry assessed by micro computed tomography. Int Endod $J$ 34:221-230, 2001.

8. Berutti E, Chiandussi G, Gaviglio I, Ibba A. Comparative analysis of torsional and bending stresses in two mathematical models of nickel-titanium rotary instruments: ProTaper versus ProFile. J Endod 29:1519, 2003.

9. Yoshimine Y, Ono M, Akamine A. The shaping effects of three nickel-titanium rotary instruments in simulated S-shaped canals. J Endod 31:373-375, 2005.

10. Yun HH, Kim SK. A comparison of the shaping abilities of 4 nickel-titanium rotary instruments in simulated root canals. Oral Surg Oral Med Oral Pathol Oral Radiol Endod 95:228-233, 2003.

11. Guelzow A, Stamm O, Martus P. Kielbassa AM. Comparative study of six rotary nickel-titanium systems and hand instrumentation for root canal preparation. Int Endod J 743-752, 2005.

12. Iqbal MK, Firic S, Tulcan J, Karabucak B, Kim S. Comparison of apical transportation between ProFile and ProTaper NiTi rotary instruments. Int Endod $J$ 37:359-364, 2004.

13. Weine FS, Kelly RF, Lio PJ. The effect of preparation procedures on original canal shape and on apical foramen shape. J Endod 1:255-262, 1975.

14. Davis RD, Marshall JG, Baumgartner JC. Effect of early coronal flaring on working length change in curved canals using rotary nickel-titanium versus stainless steel instruments. J Endod 28:438-442, 2002.

15. Dummer PMH, Alodeh MHA, Al-Omari MAO. A method for theconstruction of simulated canals in clear resin blocks. Int Endod J 24:63-66, 1991. 


\title{
국문초록
}

\section{만곡된 레진 모형 근관에서 4종의 엔진 구동형 니켈-티타늄 기구의 근관 중심율 유지 능력}

\author{
구재훈 ${ }^{1}$ 장훈상 ${ }^{1}$ - 장석우 ${ }^{1}$ - 조환희 ${ }^{1}$ - 배지명 ${ }^{2}$ - 민경산 ${ }^{*}$ \\ 원광대학교 치과대학 ${ }^{1}$ 치과보존학교실, ${ }^{2}$ 치과재료학교실
}

본 연구의 목적은 새로 시판된 NRT 기구의 근관 형태 유지 능력을 기존의 3종의 기구와 비교하는 것이다. 만곡 된 레진 모형 근관을 ProFile, K3, ProTaper, NRT 기구를 이용하여 형성하였고 형성 전, 후의 상을 스캔한 후 중첩시켜 이미지 분석 프로그램을 이용하여 근관 만곡도의 변화와 근관 중심축에 대한 근관의 변이 정도를 근관 중 심율의 변화로 계산하여 분석하였다. 근관 변이의 유의성 검정을 위해 one-way ANOVA 분석을 시행하였으며 각 기구간의 유의성 검정은 Duncan's test로 사후 분석하였다.

근첨에서 $1,2 \mathrm{~mm}$ 상방 위치에서의 근관 중심율은 ProFile 군이 다른 군에 비해 우수한 것으로 나타났다 $(\mathrm{p}<$ 0.05). NRT 기구의 근관 중심율 변화를 측정한 결과 근첨으로부터 $5 \mathrm{~mm}$ 상방에서는 Profile에 비해서만 큰 것으 로 나타났고 $6,7 \mathrm{~mm}$ 상방에서는 다른 모든 군들에 비해 큰 것으로 나타났다 $(\mathrm{p}<0.05)$.

비록 NRT 기구가 근첨 부위에서는 ProFile을 제외한 다른 기구에 비해 유의차 없는 중심률 유지 능력을 보였으 나 근관 입구 및 중간부위의 형성에 사용되는 스테인레스-스틸 파일로 인해 coronal flaring시 다른 기구들에 비해 더 많은 중심률의 변화를 보이는 것으로 사료된다.

주요어: 니켈-티타늄, 레진 모형 근관, 중심율, NRT, 스테인레스-스틸 